\title{
Stress-Strain behaviour of basalt fibre reinforced concrete
}

\author{
E Giri Prasad Goud ${ }^{1}$, Dinesh Singh ${ }^{2}$, V Srinivasa Reddy $^{3}$, Kaveli Jagannath Reddy ${ }^{4}$ \\ ${ }^{1}$ Research Scholar of Civil Engineering, K L University, Andhra Pradesh, India \\ ${ }^{2}$ Department of Civil Engineering, K L University, Andhra Pradesh, India \\ ${ }^{3}$ Professor, Department of Civil Engineering, GRIET, Hyderabad, India \\ ${ }^{4}$ B.Tech Student, Department of Civil Engineering, GRIET, Hyderabad, India
}

\begin{abstract}
This paper prophesies the stress strain behaviour of M30 grade concrete reinforced with basalt fibres of length $12 \mathrm{~mm}, 36 \mathrm{~mm}$ and $50 \mathrm{~mm}$ of amounts $0.4 \%, 0.4 \%$ and $0.3 \%$ by volume of concrete respectively. Modulus of elasticity and toughness of M30 grade basalt fibre reinforced concretes are also evaluated. It was found that BFRCC mixes show good resistance to impact and has superior dissipation capacity. The optimal basalt fibre volume fraction is $0.3 \%$ and length is 50 $\mathrm{mm}$. For this case, toughness index and energy absorbed at fracture have considerably enhanced. With the volume fraction of basalt fiber exceeding the optimum volume fraction, the mechanical properties of basalt fiber are weakened.
\end{abstract}

\section{Introduction}

Basalt fibres improves the cracking behaviour of concrete and improves the failure pattern mode to non-brittle. Many researchers' debated on the mix quantities of basalt fibre in refining strength properties of concrete. J Wang et al. (2014) used fibres of length $30 \mathrm{~mm}$ and dosage of $0.1 \%$, F Chen et al. (2013) adopted fibres of length $24 \mathrm{~mm}$ and dosage of $0.04 \%$, N Kabay et al. (2014) preferred fibres of length 24 $\mathrm{mm}$ and dosage of $0.16 \%$, C Jiang et al. (2014) examined fibres of length $12 \mathrm{~mm}$ and dosage of $0.3 \%$, A B Kizilkanat et al. (2015) used fibres of length $12 \mathrm{~mm}$ and dosage of $0.25 \%$, Z O Pehlivanh et al. (2015) used fibres of length 8 $\mathrm{mm}$ and dosage of $0.304 \%$, S Jalasutram et al. (2017) used fibres of length $12.7 \mathrm{~mm}$ and dosage of $0.1 \%$, M E Arslan et al. (2016) used fibres of length $24 \mathrm{~mm}$ and dosage of $0.07 \%$, J Branston et al. (2016) used fibres of length $36 \mathrm{~mm}$ and dosage of $0.46 \%$ and $\mathrm{H}$ Katkhuda et al. (2016) used fibres of length $18 \mathrm{~mm}$ and dosage of $0.3 \%$,

\section{Methodology}

The objective of this work is to evaluate experimentally the stress-strain performance of M30 grade fibre reinforced concretes made with basalt fibres of length $12 \mathrm{~mm}, 36 \mathrm{~mm}$ and $50 \mathrm{~mm}$ of amounts $0.4 \%, 0.4 \%$ and $0.3 \%$ by volume of concrete respectively. Basalt fibre reinforced concretes cylinders of size $150 \mathrm{~mm}$ diameter x $300 \mathrm{~mm}$ height are casted and cured for 28 days and tested in Uniaxial compression under strain control as per IS: 516-1999 to comprehend the stress-strain performance of M30 grade basalt fibre reinforced concretes (BFRCC).

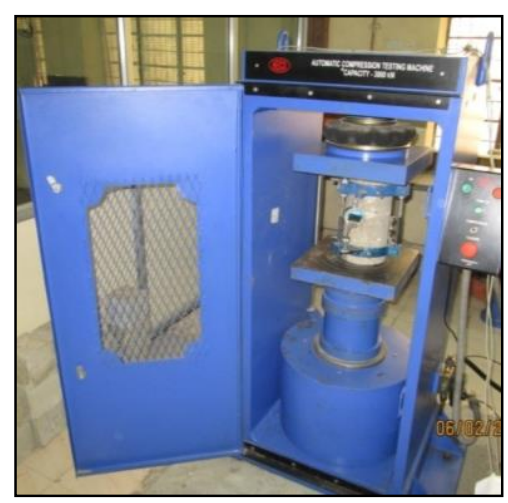

Fig. 1. Test arrangement for stress-strain analyses

\section{Optimum dosage of fibre}

The Fig. beneath displays the compressive strengths of BFRCC mixes made with various lengths and dosages of fibre volume. It can be see that for different lengths, the optimal amount of fibre required is varying. In this case for M30 grade BFRCC, the length considered for examination are $12 \mathrm{~mm}, 36 \mathrm{~mm}$ and $50 \mathrm{~mm}$ based on the availability in the market. Various quantities such as $0.2 \%, 0.3 \%$ and $0.4 \%$ are selected based on the past research studies. It was found 
that compressive strength of $12 \mathrm{~mm}$ length $+0.4 \%$ fibre, 36 mm length $+0.4 \%$ fibre and $50 \mathrm{~mm}$ length $+0.3 \%$ fibred BFRCC mixes gave maximum strengths so forwards now examinations are carried out on effect of these combinations in various elements and properties of BFRCC mixes. For comparative purpose, concrete mixes without basalt fibres are also prepared.

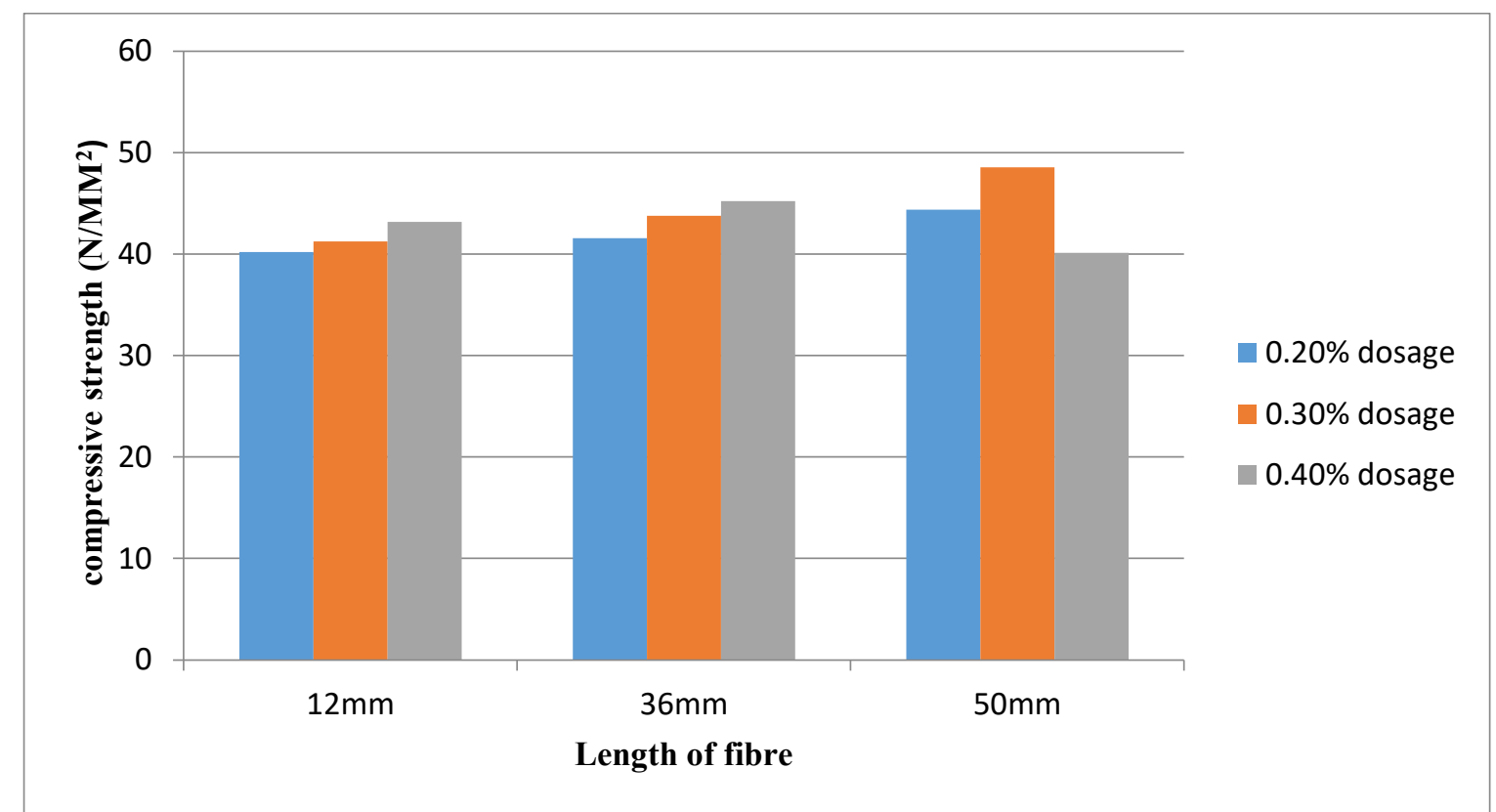

Fig. 2. Effect of fibre lengths and dose on the compressive strength

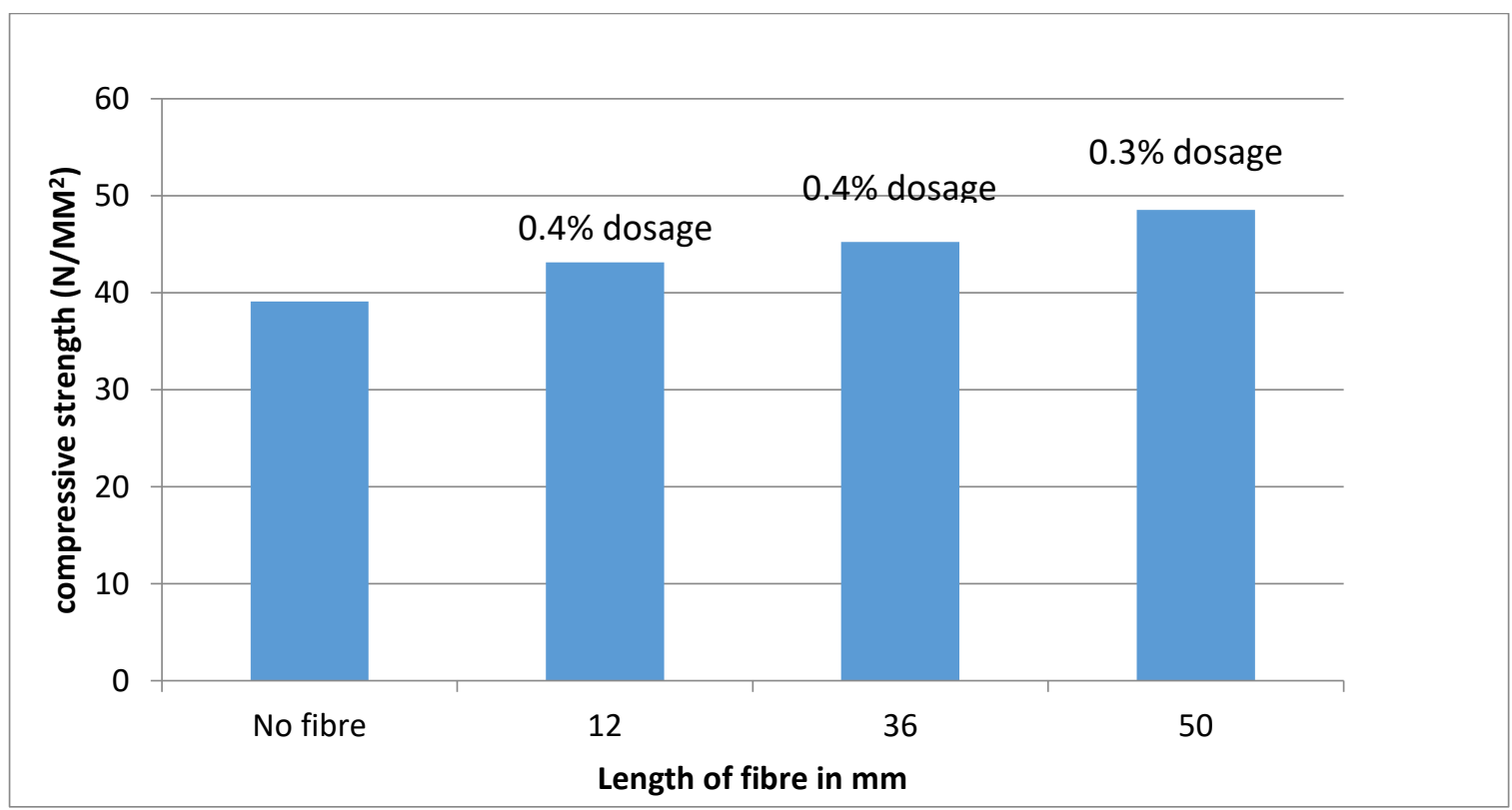

Fig. 3. Optimum dose for different fibre lengths and corresponding compressive strengths

\section{Stress-strain investigation on BFRCC mixes}

The investigations to assess stress strain values of various length and dose combinations of M30 BFRCC mixes. 
Cylinders are uniaxially compressed under strain controlled rate of loading.

Table 1. Stress strain values of various length and dose combinations of BFRCC mixes

\begin{tabular}{|c|c|c|c|c|c|c|c|}
\hline \multicolumn{2}{|c|}{$0 \%$ fibre } & \multicolumn{2}{|c|}{$\begin{array}{c}12 \mathrm{~mm} \text { length }+0.4 \% \text { fibre } \\
\text { BFRCC }\end{array}$} & \multicolumn{2}{|c|}{$\begin{array}{c}36 \mathrm{~mm} \text { length }+0.4 \% \text { fibre } \\
\text { BFRCC }\end{array}$} & \multicolumn{2}{|c|}{$\begin{array}{c}50 \mathrm{~mm} \text { length }+0.3 \% \text { fibre } \\
\text { BFRCC }\end{array}$} \\
\hline Strain & Stress(MPa) & Strain & Stress $(\mathrm{MPa})$ & Strain & Stress(MPa) & Strain & Stress(MPa) \\
\hline 0 & 0 & 0 & 0 & 0 & 0 & 0 & 0 \\
\hline 0.000167 & 3.008281 & 0.00013 & 2.757046 & 0.006 & 0 & 0.000037 & 0.216442 \\
\hline 0.000303 & 6.181143 & 0.000315 & 5.909672 & 0.000013 & 45.19565 & 0.00028 & 5.856222 \\
\hline 0.00053 & 9.858162 & 0.000574 & 10.04824 & 0.000037 & 0.391304 & 0.000523 & 10.19168 \\
\hline 0.000712 & 13.36644 & 0.000778 & 13.39823 & 0.00043 & 7.826087 & 0.000821 & 14.95907 \\
\hline 0.000985 & 17.54553 & 0.001074 & 16.94901 & 0.000691 & 12.52174 & 0.000952 & 18.21327 \\
\hline 0.001258 & 22.39128 & 0.001241 & 20.29728 & 0.000952 & 16.04348 & 0.001214 & 23.41733 \\
\hline 0.00147 & 25.56761 & 0.0015 & 23.84635 & 0.001232 & 20.34783 & 0.001549 & 26.44374 \\
\hline 0.001758 & 29.08075 & 0.001648 & 26.60425 & 0.001419 & 25.43478 & 0.001791 & 30.77919 \\
\hline 0.001939 & 32.42235 & 0.001889 & 29.36644 & 0.001754 & 28.17391 & 0.002238 & 34.45209 \\
\hline 0.002212 & 34.26816 & 0.002111 & 32.32428 & 0.002015 & 31.69565 & 0.002592 & 37.91233 \\
\hline 0.002485 & 35.11397 & 0.002352 & 34.69347 & 0.002351 & 35.02174 & 0.002852 & 39.20342 \\
\hline 0.002727 & 34.95842 & 0.002519 & 36.86273 & 0.002742 & 37.56522 & 0.003001 & 40.06541 \\
\hline 0.003015 & 33.80497 & 0.002778 & 37.46425 & 0.003058 & 40.30435 & 0.003262 & 41.79127 \\
\hline 0.003182 & 30.47933 & 0.002926 & 39.82915 & 0.003151 & 41.28261 & 0.003522 & 43.29975 \\
\hline 0.00353 & 27.49536 & 0.003111 & 38.85521 & 0.003522 & 39.13044 & 0.003838 & 41.54458 \\
\hline 0.003712 & 23.67042 & 0.00337 & 37.88471 & 0.00367 & 35.80435 & 0.004079 & 40.01059 \\
\hline 0.003894 & 21.01214 & 0.003685 & 35.34476 & 0.003892 & 33.45652 & 0.00432 & 37.60704 \\
\hline 0.004197 & 18.52607 & 0.003889 & 33.58568 & 0.004096 & 31.30435 & 0.004542 & 36.07399 \\
\hline 0.004379 & 16.03444 & 0.004222 & 31.8326 & 0.004337 & 28.95652 & 0.004709 & 34.32638 \\
\hline 0.004561 & 15.54279 & 0.004352 & 29.08756 & 0.004633 & 26.6087 & 0.004968 & 31.70451 \\
\hline & & 0.004537 & 26.73811 & & & & \\
\hline & & 0.004741 & 24.97902 & & & & \\
\hline & & 0.004944 & 23.41644 & & & & \\
\hline
\end{tabular}

If the crack patterns are observed the characteristic failure is by vertically developed cracks for $12 \mathrm{~mm}$ and $36 \mathrm{~mm}$ fibre lengths and dosage of $0.4 \%$ because of failure at localized areas whereas for $50 \mathrm{~mm}$ fibre length of $0.3 \%$ fibre volume the cracks are developed diagonally due multiple cracks leading to failure at high strain and also stress redistribution is expected to happen at $50 \mathrm{~mm}$ fibre length of $0.3 \%$ fibre volume. The mode of failure of BFRCC is transformed to non-brittle failure due to integration of basalt fiber. So, by witnessing the failure mechanics of basalt fibers at the section of failure, it can be adjudicated that there exists a good bond between basalt fiber and concrete matrix.

Stresses endured by $50 \mathrm{~mm}$ fibre length $+0.3 \%$ fibre dosage BFRCC mix is found to be ultimate when compared with the stress-strain responses of the other BFRCC mixes with fibre less than $50 \mathrm{~mm}$. 


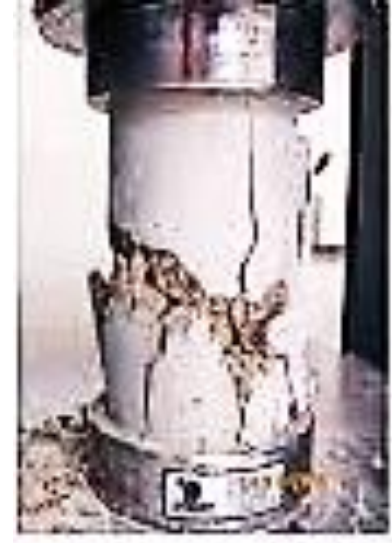

(a)

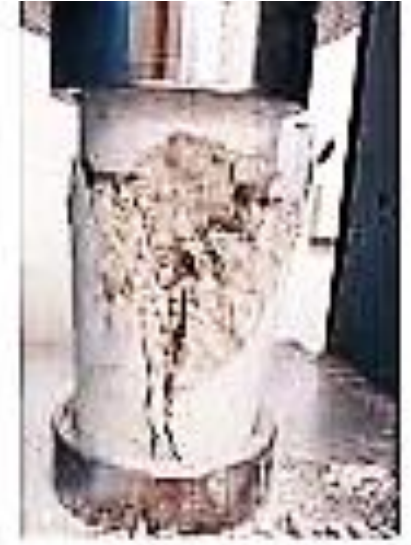

(b)

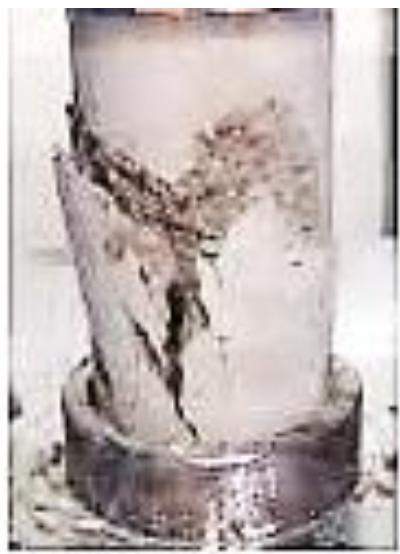

(c)

Fig. 4. Failure patterns of (a) $12 \mathrm{~mm}$ length $+0.4 \%$ fibre (b) $36 \mathrm{~mm}$ length $+0.4 \%$ fibre (c) $50 \mathrm{~mm}$ length $+0.3 \%$ fibre

Table 2. Strains at peak and ultimate stresses

\begin{tabular}{|c|c|c|c|c|}
\hline \multirow{2}{*}{$\begin{array}{c}\text { M30 grade BFRCC } \\
\text { Type }\end{array}$} & $\begin{array}{c}\text { Stress at Ultimate load } \\
(\mathrm{MPa}) \\
\sigma\end{array}$ & $\begin{array}{c}\text { Corresponding strain } \\
\text { at Ultimate load } \\
\varepsilon_{1}\end{array}$ & $\begin{array}{c}\text { Ultimate } \\
\text { Strain } \\
\varepsilon_{2}\end{array}$ & $\begin{array}{c}\text { Strain ratio } \\
\varepsilon_{2 /}\end{array}$ \\
\hline $\begin{array}{c}\varepsilon_{1} \\
\text { 0\% fibre }\end{array}$ & 35.11 & 0.002485 & 0.004561 & 1.84 \\
\hline $12 \mathrm{~mm}$ length $+0.4 \%$ fibre & 39.83 & 0.002926 & 0.004944 & 1.69 \\
\hline $36 \mathrm{~mm}$ length $+0.4 \%$ fibre & 41.28 & 0.003151 & 0.004633 & 1.47 \\
\hline $50 \mathrm{~mm}$ length $+0.3 \%$ fibre & 43.30 & 0.003522 & 0.004968 & 1.41 \\
\hline
\end{tabular}

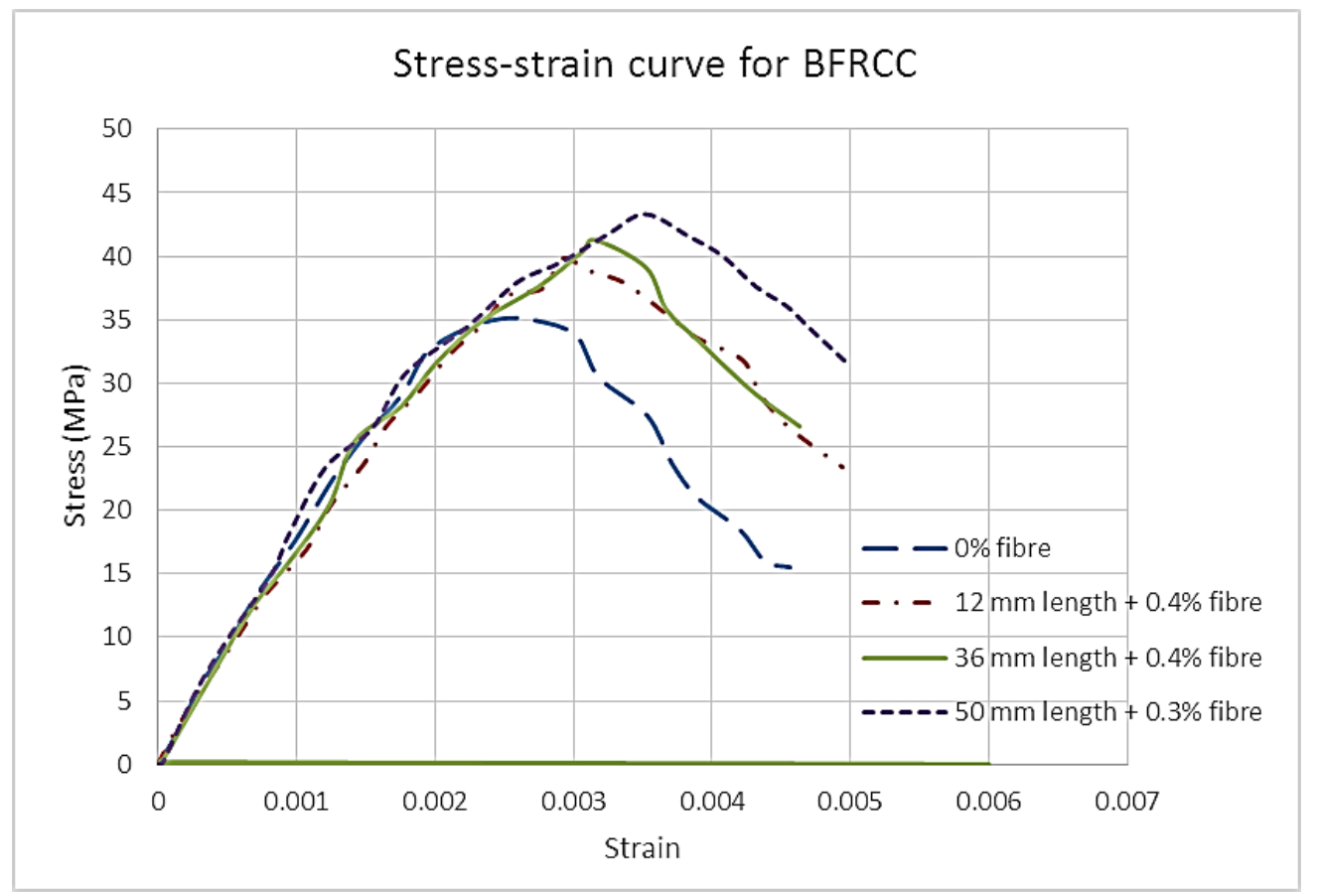

Fig. 4. Stress-strain curve for BFRCC 
In normal concrete the stress is found to be attaining peak value for a strain value of 0.002 and afterwards stress decreases which indicated by a dipping curve till ultimate crushing strain is reached. In BFRCC mixes the strain at peak value of stress is more than 0.002 showing its ability to endure more strain without normal failure. As the stresses increases, the pre-peak curve becomes nonlinear and the post-peak curve which indicates strain capability also decreases. The curve beyond post peak is directly related to the fibre length and fibre dose and it is virtually steep as arising curve for 12 and $36 \mathrm{~mm}$ fibre lengths and is further progressively inclined for the $50 \mathrm{~mm}$ fibre lengths. Dosage required decreases as fibre length increases.

Table 3. Elastic Modulus (E) and toughness

\begin{tabular}{|c|c|c|}
\hline \multirow{2}{*}{\begin{tabular}{c} 
M30 $\begin{array}{c}\text { grade BFRCC } \\
\text { Type }\end{array}$ \\
\cline { 2 - 3 }
\end{tabular}} & $\begin{array}{c}\text { Elastic Modulus (E) and Toughness Modulus } \\
\text { Toughness Modulus } \\
\text { MPa }\end{array}$ \\
\hline $0 \%$ fibre & GPa & 0.066 \\
\hline $12 \mathrm{~mm}$ length $+0.4 \%$ fibre & 32.29 & 0.070 \\
\hline $36 \mathrm{~mm}$ length $+0.4 \%$ fibre & 34.67 & 0.080 \\
\hline $50 \mathrm{~mm}$ length $+0.3 \%$ fibre & 37.88 & 0.084 \\
\hline
\end{tabular}

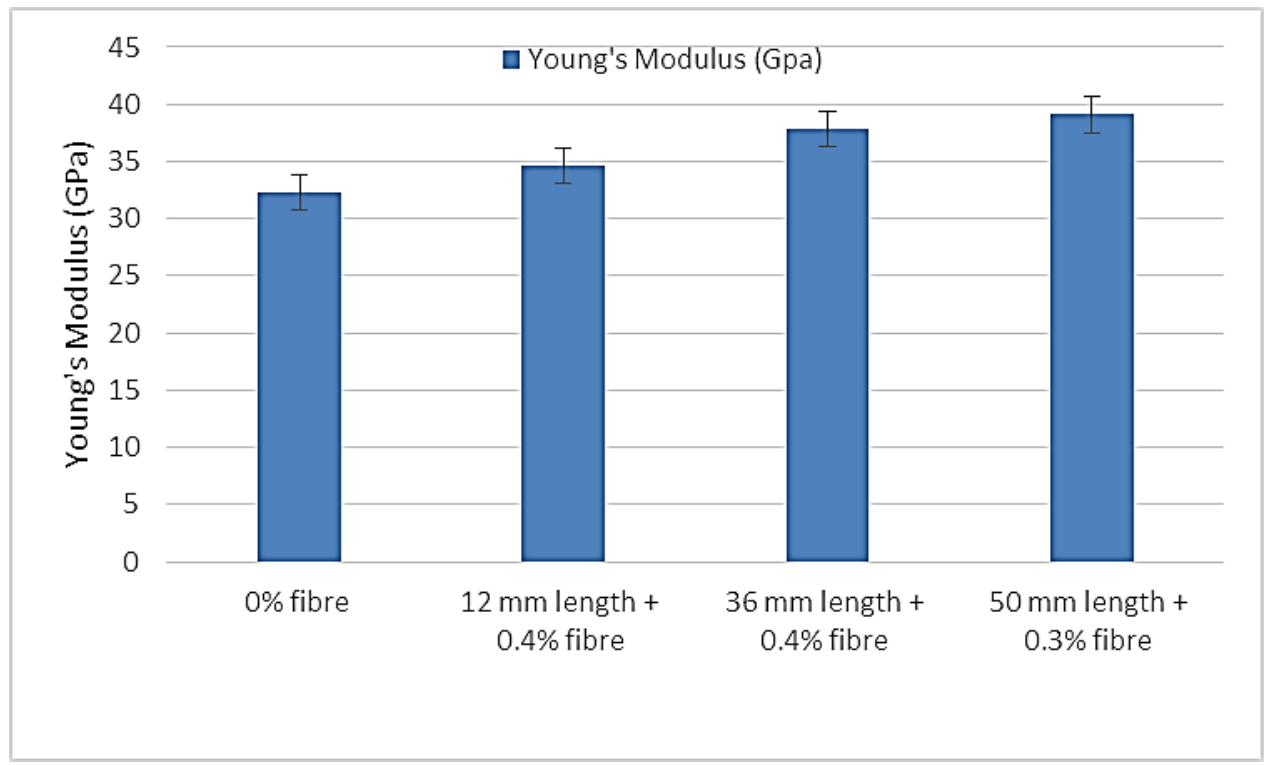

Fig. 5. Variation of ' $E$ ' based on fibre length and fibre dose

\section{Conclusions}

From the interpretations from the stress-strain curves, the resulting conclusions are presented below:

1. BFRCC has displayed enhanced stress values for the similar strains as length of fibres and dose increases.

2. The strain at ultimate stress is marginally more, and the slope of the descending part is steeper due to the decrease in the extent of internal micro cracking in bacteria induced concrete

3. Ares underneath stress-strain plot gives the energy relieving ability of the concrete. BFRCC mixes has high energy dissipation ability due to fibres. As length of fibre increases impact resistance also increases similarly as dose increases the impact energy dissipation increases in BFRCC mixes due to fibres will control the cracks length and width formation by disintegrating distortion energy. 
4. Improvement in moduli of toughness value in BFRCC mixes imply its developed resistance to impact. It is witnessed that Elastic modulus (E) is moderately increased for all BFRCC mixes as fibre lengths and added volume fraction increases indicating its better performance.

\section{References}

1. Benjamin A.Graybeal, (2007), "Compressive Behavior of Ultra-High-Performance Fibrereinforced Concrete" ACI Materials Journal, March/April(2007), pp. 146-152.

2. Chang, T.P., Chen, B.T., Wang, J.J., and Wu, C.S., (2009)"Performance of RPC with Different Conditions and its Retrofitting Effects on cxoncrete members", Proc., Concrete Repair, Rehabilitation and Retrofitting I, Ed. Alexander et al, Taylor and Francis Group, London, pp.12031207

3. Dattatreya, J.K., Harish, K. V. and Neelamegam,M., " Use of Particle Packing Theory for the Development of Reactive Powder Concrete", The Indian Concrete Journal , September (2007), pp 31-45.

4. Tummala Suresh Kumar, Kosaraju Satyanarayana, Materials Today: Proceeding, 26 (2), 3228-3233, (2020).

5. Ezheldin, AS and Balaguru, PN, (1999), "Normal and High Strength FRC Under Compression", Journal of Materials in Civil Engineering, Vol. 4, No. 4, (1999), pp 415-429

6. Harish,K.V., Dattatreya,J.K., Sabitha,D. and Neelamegam,M.,(2008) " Role of Ingredients and of Curing Regime in Ultra High Strength Powder Concrete", Journal of Structural Engineering, Vol.34, No.6, February-March (2008), pp.421-428

7. Jungwirth J.,(2002) "Underspanned Bridge Structures in Reactive Powder Concrete", 4th International $\mathrm{PhD}$ Symposium in Civil Engineering, Munich, Germany,2002

8. Malik, Adnan R, Foster, and Stephen J.,(2010) "Carbon Fibre Reinforced Polymer Confined Reactive Powder Concrete Columns Experimental Investigation”,ACI Structural Journal, May 2010

9. Bankupalli, P.T., Srikanth Babu, V., Suresh Kumar. T, International Journal of Applied Engineering Research, 10(16), pp: 37057-37062 (2015).

10. Richard p. and Cheyrezy M.H., (1995) "composition of reactive powder concrete",
Cement and concrete research 25(7): pp.15011511

11. RILEM TC 148-SSC, (2000) Recommendations of TC 148-SSC: "Strain Softening of Concrete - Test methods for compressive softening Test method for measurement of the strain-softening behaviour of concrete under uniaxial compression", Materials and Structures, Vol. 33, pp 347-351. 